\title{
Peningkatan Hasil Belajar Tematik Melalui Problem Based Learning Dalam Pembelajaran Daring Siswa Kelas IV SD
}

\author{
Ratna Hapsari Putri*, Naniek Sulistya Wardani² \\ 12 Universitas Kristen Satya Wacana, Salatiga, Indonesia \\ *e-mail: ratnahapsari64@gmail.com
}

\begin{abstract}
Abstrak
Pelaksanaan pembelajaran tematik yang dilakukan secara daring berpusat pada guru sehingga membuat siswa tidak aktif saat mengikuti pelajaran. Tujuan penelitian ini adalah untuk mengetahui apakah terjadi peningkatan hasil belajar siswa kelas IV SD melalui Problem Based Learning (PBL) dalam pembelajaran daring. Jenis penelitian ini adalah penelitian tindakan kelas (PTK). Model PTK yang digunakan adalah spiral dari C. Kemmis dan Mc Taggart. Prosedur penelitian minimal menggunakan 2 siklus dengan catatan apabila setiap siklus menunjukkan kenaikan hasil belajar, masingmasing siklus terdiri dari perencanaan, pelaksanaan tindakan dan observasi, dan refleksi. Teknik pengumpulan data menggunakan teknik tes dan non tes. Instrumen penelitian berupa butir soal dan lembar observasi. Teknik analisis data yang digunakan adalah uji $\mathrm{T}$ dan uji N-Gain. Hasil dari penelitian menunjukkan model pembelajaran Problem Based Learning berpengaruh pada hasil belajar siswa kelas IV SD melalui PBL dalam pembelajaran daring. Dapat disimpulkan bahwa model pembelajaran PBL dapat meningkatkan hasil belajar siswa. Implikasi penelitian ini memberi dampak pada suasana belajar yang aktif dan menyenangkan sehingga dapat meningkatkan hasil belajar siswa.
\end{abstract}

Kata kunci: PBL, tematik, pembelajaran daring

\begin{abstract}
Implementation of thematic learning that is carried out online is centered on the teacher so that it makes students inactive while participating in lessons. This study aims to determine whether there was an increase in learning outcomes of fourth grade elementary school students through Problem Based Learning (PBL) in online learning. This type of research is classroom action research (PTK). The PTK model used was a spiral from Kemmis and Taggart. The research procedure at least uses 2 cycles provided that each cycle shows an increase in learning outcomes, each cycle consisting of planning, implementing action and observation, and reflection. Data collection techniques used test and non-test techniques. Research instruments in the form of items and observation sheets. The data analysis technique used was the $T$ test and N-Gain test. The results of the study indicate that the Problem Based Learning model has an effect on the learning outcomes of fourth grade elementary school students through PBL in online learning. It can be concluded that the PBL learning model can improve student learning outcomes. The implication of this research has an impact on an active and fun learning atmosphere so that it can improve student learning outcomes.
\end{abstract}

Keywords: PBL, thematic, online learning

\section{Pendahuluan}

Pembelajaran pada masa pandemi covid-19 dilakukan secara daring (jarak jauh), pembelajaran daring tersebut merupakan pembelajaran secara online melalui aplikasi media sosial sehingga mewajibkan guru untuk melakukan pembelajaran setiap hari dari jarak jauh.

\footnotetext{
${ }^{*}$ Corresponding author.

Received 30 Januari 2021; Accepted 1 Maret 2021; Available online 8 April 2021 (C) 2021 MI All Rights Reserved
} 
Pembelajaran daring membuat guru dituntut dapat menyampaikan materi secara jelas yang dapat mencapai tujuan pembelajaran (Lattu, 2012; Mustikaningrum, Pramusinta, Ayu, \& Umar, 2020). Pembelajaran daring adalah pembelajaran yang memanfaatkan jaringan internet sehingga siswa memiliki keluasan dalam belajar. Siswa dapat berinteraksi melalui beberapa aplikasi seperti classroom, video converence, telepon atau live chat, zoom maupun whatsapp group (Batubara \& Batubara, 2020; Isman, 2017). Pembelajaran daring merupakan jawaban sumber belajar inovatif karena salah satu bagian dari inovasi pendidikan. Inovasi pendidikan tersebut dapat tercapai dengan baik bergantung dari karakteristik peserta didik (Nakayama, Yamamoto, \& Santiago, 2007; Tafqihan, 2011). Tidak semua peserta didik akan berhasil dalam mengikuti pembelajaran online, karena keberhasilan tersebut dipengaruhi oleh faktor lingkungan belajar dan karakteristik peserta didik (Jamil, 2014). Pada pembelajaran daring guru menyampaikan tujuan pembelajaran yang akan dicapai dengan pembelajaran tematik.

Permasalahan yang terjadi saat ini adalah masih banyak siswa yang kurang memahami pembelajaran tematik. Hal ini disebabkan karena guru menggunakan model pembelajaran konvensional sehingga siswa merasa bosan dalam belajar (Arianti, Wiarta, \& Darsana, 2019b; Khoeriyah \& Mawardi, 2018; Wulandari, Sudatha, \& Simamora, 2020). Pembelajaran yang berpusat pada guru membuat siswa tidak aktif dalam belajar (Arianti, Wiarta, \& Darsana, 2019a). Permasalahan ini juga ditemukan pada salah satu sekolah dasar. Berdasarkan hasil observasi yang telah dilakukan di SD Negeri Plumutan, nampak bahwa dalam pelaksanaan pembelajaran tematik yang dilakukan secara daring berpusat pada guru. Materi pembelajaran dan tugas dibagikan melalui media aplikasi whatsapp group (WAG). Tugas yang diberikan sama dengan yang ada di buku tema. Guru menjelaskan materi pembelajaran melalui WAG. Nampak dalam WAG, tidak ada respon dari siswa yang diberikan, tidak ada siswa yang mengajukan pertanyaan dalam WAG. Pada pembelajaran, siswa menerima permasalahan dari guru, namun dalam memecahkan permasalahan dijawab oleh guru sendiri. Ada pembentukan kelompok untuk mendiskusikan pembelajaran. Namun, diskusi tidak dapat berjalan secara interaktif. Komunikasi yang ada dalam WAG hanya sekedar informasi dan materi saja yang diberikan oleh guru, tidak terdapat aktivitas interaksi antara siswa dengan guru. Penyusunan RPP tidak didesain dengan menggunakan pendekatan dan model pembelajaran.

Selain itu, metode pembelajaran yang digunakan yaitu ceramah, tanya jawab, dan diskusi. Tujuan pembelajaran yang digunakan guru berada pada level kognitif C1-C3 (mengingat, memahami, dan menerapkan). Langkah-langkah pembelajaran belum menunjukkan langkah-langkah yang mengarah pada pendekatan. Namun, pada langkahlangkah pembelajaran ada diskusi meskipun pada penerapannya kegiatan diskusi tersebut tidak berjalan secara aktif antara guru dan siswa atau siswa dengan temannya. Penilaian pembelajaran yang dilakukan melalui penilaian ulangan harian setiap tema. Nilai yang dipertimbangkan untuk mengisi raport adalah nilai ulangan harian, nilai PTS, dan nilai PAS. Hasil belajar mestinya diukur melalui penilaian sikap dengan menggunakan lembar observasi, penilaian kognitif melalui tes dan penilaian psikomotor dilakukan melalui pengamatan terhadap unjuk kerja siswa. Dalam pembelajaran daring, hasil belajar yang dilakukan berupa penilaian kognitif, sedangkan penilaian sikap dan psikomotorik belum nampak dilakukan. Dari penilaian hasil belajar, nampak bahwa rata-rata skor belajar siswa mencapai 65,14 . Jika KKM $\geq 80$, maka seluruh siswa tidak tuntas. Hal ini nampak juga dari 21 siswa, siswa yang tuntas sebanyak 9 siswa (42,86\% dari seluruh siswa). Dengan demikian siswa tidak tuntas mencapai lebih dari $50 \%$ yakni sebanyak 12 siswa $(57,14 \%$ dari seluruh siswa). Dapat disimpulkan bahwa pelajaran tematik tidak dapat dipahami dengan baik oleh siswa.

Pembelajaran tematik terpadu adalah pembelajaran yang memuat konsep pembelajaran dengan tema yang mengaitkan beberapa mata pelajaran sehingga dapat memberikan pengalaman yang bermakna bagi peserta didik (Firdaus \& Badriyah, 2018; Hajar, 2013). Pembelajaran tematik pada pengertian tersebut artinya guru merancang pembelajaran berdasarkan tema-tema tertentu dan membahas tema-tema dari berbagai 
materi pelajaran yang tersedia, misalnya tema indahnya keragaman di negeriku dapat dibahas melalui mata pelajaran Bahasa Indonesia dan IPA dan tema indahnya keragaman di negeriku juga dapat dibahas melalui materi-materi pelajaran lain seperti IPS, PPKn ataupun SBdP. Tema dalam pembelajaran tematik terpadu dikelas IV semester II terdiri dari empat tema yaitu Tema 6. Cita-Citaku, Tema 7. Indahnya Keragaman di Negeriku, Tema 8. Daerah Tempat Tinggalku, Tema 9. Kayanya Negeriku. Setiap satu tema terdapat 3 subtema dan setiap sub tema dilaksanakan dalam 6 pembelajaran. Proses pembelajaran tematik dilakukan dengan pembelajaran yang berfokus pada siswa agar siswa dapat berpikir kritis, aktif, kreatif dalam memecahkan masalah dan menyampaikan informasi untuk pemecahan masalah (Prasetya, Ade Yama Wahyu Nur, Dedi Kuswandi, 2018; Wuryani \& Yamtinah, 2018). Pada umumnya masalah proses pembelajaran tematik yang terjadi yaitu pembelajaran yang dilakukan masih berpusat pada guru. Pembelajaran masih berpusat pada guru ini terlihat pada pelaksanaan pembelajaran dengan guru menyampaikan materi pembelajaran melalui ceramah dan tidak ada diskusi dengan siswa.

Beberapa permasalahan yang muncul, perlu dipecahkan dengan meningkatkan hasil belajar siswa melalui desain pembelajaran yang membelajarkan siswa. Proses pembelajaran yang dilakukan oleh guru sangat berpengaruh terhadap hasil belajar siswa (Mulyadin, 2016; Ulinnuha, Budi Waluya, \& Rochmad, 2021). Salah satu pemebelajaran yang perlu diterapkan supaya siswa dapat mengkonstruk pengetahuanya sendiri adalah problem based learning (PBL) (Phungsuk, Viriyavejakul, \& Ratanaolarn, 2017; Wyness \& Dalton, 2018). Dalam pembelajaran yang menggunakan pendekatan PBL, dapat membuat siswa lebih aktif, kreatif, dan inovatif dalam meningkatkan hasil belajar tematik. Wayan Sadia (2014) mengungkapkan bahwa PBL merupakan pembelajaran yang berpusat pada siswa dan memacu siswa untuk aktif dalam pembelajaran dengan memecahkan suatu masalah. PBL merupakan pembelajaran yang penyampaiannya dilakukan dengan cara menyajikan suatu permasalahan, mengajukan pertanyaan-pertanyaan, memfasilitasi penyelidikan, dan membuka dialog. Pembelajaran ini dapat membuat siswa belajar melalui upaya penyelesaian permasalahan dunia nyata secara terstruktur untuk mengkonstruksi pengetahuan siswa (Abdulloh, 2015; Şendağ \& Ferhan Odabaşi, 2009). Keberhasilan pembelajaran PBL dapat dilihat pada hasil belajar siswa.

Penelitian yang dilakukan oleh Setyosari (2017) menunjukkan bahwa melalui pendekatan PBL, pada siklus 1 siswa mencapai ketuntasan sebanyak 16 siswa (64\% dari 25 siswa) dan pada siklus 2 hasil belajar yang mencapai ketuntasan mencapai 22 siswa (88\% dari 25 siswa). Penelitian ini lebih memfokuskan pada hasil belajar berdasarkan ketuntasan, dan teknik analisis data yang digunakan adalah teknik deskriptif komparatif. Sejalan dengan hasil penelitian dari Febrita \& Harni (2020) yang menyimpulkan bahwa tindakan PBL dapat meningkatkan hasil pembelajaran sebesar $31,03 \%$, hal ini nampak bahwa kegiatan pembelajaran PBL belum berjalan dengan baik. Pembelajaran PBL yang dilakukan, merupakan pembelajaran yang baru pertama kali. Hal ini didukung dengan pelaksanaan pembelajaran pada siklus 2 , peningkatannya sudah dapat mengangkat untuk mencapai ketuntasan. Maka pembelajaran PBL dapat meningkatkan hasil belajar siswa. Penelitian Suari, Ni, (2018) peningkatan ketuntasan hasil belajar sudah terjadi sejak siklus 1 mencapai $68 \%$ dari seluruh siswa. Yuniawardani \& Mawardi, (2018) menyimpulkan ketuntasan hasil belajar mencapai $(66,7 \%)$ dari seluruh siswa.

Wardani (2010) menjelaskan bahwa sudah ada guru yang berusaha melakukan penilaian berpikir melalui pemberian tugas atau PR dalam bentuk soal subjektif dan masih banyak guru yang belum mengerti dengan benar cara melakukan penilaian aspek afektif apalagi proses ilmiah. Hal ini mengindikasikan perlunya penelitian tentang pengukuran. Dalam penelitian ini menekankan pada hasil belajar yang mengukur proses pembelajaran yang berupa lembar observasi dan lembar observasi untuk unjuk kerja, serta mengukur hasil pembelajaran melalui tes. Kurikulum 2013 pada tingkat sekolah dasar menyebutkan bahwa penilaian sikap dapat dilakukan pada proses pembelajaran kurikuler maupun ekstrakurikuler.

Berdasarkan pengamatan di lapangan dan hasil penelitian yang relevan, maka tujuan dari penelitian ini yaitu untuk mengetahui peningkatan hasil belajar tematik siswa kelas IV 
SD dalam pembelajaran daring melalui model pembelajaran Problem Based Learning. Diharapkan model pembelajaran Problem Based Learning dapat meningkatkan hasil belajar tematik pada siswa kelas IV SD.

\section{Metode}

Penelitian ini dilaksanakan di SD Negeri Plumutan Kecamatan Bancak Kabupaten Semarang pada kelas IV semester 2 tahun pelajaran 2020/2021. Subyek penelitian ini adalah siswa kelas IV yang berjumlah 21 siswa, terdiri dari 11 siswa laki-laki dan 10 siswa perempuan. Jenis penelitian ini adalah penelitian tindakan kelas (PTK). Prosedur PTK ini terdiri dari tiga tahapan yaitu perencanaan, tindakan dan observasi, refleksi. Model PTK yang digunakan adalah model spiral dari C. Kemmis dan Mc Taggart.

Teknik pengumpulan data dalam PTK ini menggunakan teknik tes dan teknik non-tes. Teknik tes untuk mengukur aspek kognitif, teknik non tes untuk mengukur aspek afektif dan psikomotorik. Teknik tes diberikan di akhir pembelajaran setelah proses pembelajaran selesai dilaksanakan dan teknik nontes dilakukan selama proses pembelajaran dari awal hingga akhir. Instrumen penelitian yang digunakan adalah butir soal untuk teknik tes, lembar observasi untuk teknik non tes. Instrumen diuji cobakan kepada 20 siswa untuk menghitung validitas dan reabilitas. Instrumen terdiri dari 15 butir soal. Hasil uji validitas menunjukkan $0,464<r<0,816$ maka hasil uji validitas berada pada validitas cukup sampai validitas sangat tinggi. Maka instrumen yang diuji cobakan adalah valid. Reliabilitas instrumen dinyatakan dengan koefisien Alpha ( $\alpha$ ). $\alpha=0,72$, maka reliabilitas instrumen tinggi.

Teknik analisis data yang digunakan dalam penelitian ini menggunakan uji T untuk mengetahui rata-rata hasil belajar siswa dan uji $\mathrm{N}$-Gain untuk mengetahui peningkatan kategori rata-rata dari pra siklus, siklus I, siklus II. Uji normalitas digunakan sebagai uji prasayarat dalam uji $\mathrm{T}$ dan uji $\mathrm{N}$-Gain. Uji normalitas data ini bertujuan untuk mengetahui apakah siswa kelas IV SD Negeri Plumutan berdistribusi normal atau tidak. Berdasarkan perhitungan uji normalitas terhadap siswa kelas IV menunjukkan nilai signifikansi 0,087 > 0,05 , maka distribusi siswa normal.

\section{Hasil dan Pembahasan}

Penelitian ini terbagi menjadi dua siklus. Siklus 1 dimulai dengan membuat perangkat pembelajaran daring (PPD) yang terdiri dari RPP dengan desain pembelajaran PBL, materi pembelajaran dengan tema 7, media pembelajaran berupa powerpoint, LKPD dan evaluasi pembelajaran. Implementasi PPD terdiri dari tiga kali pertemuan. Siklus II dilaksanakan dalam dua kali pertemuan dengan tahapan yaitu tahap perencanaan, tahap pelaksanaan tindakan dan observasi, dan tahap refleksi. Aktivitas pembelajaran yang dilakukan oleh guru dan siswa dalam siklus 2, dilakukan secara rinci melalui penjelasan berikut ini. Tahap perencanaan dilakukan dengan guru membuat perangkat pembelajaran berupa RPP, bahan ajar, LKPD, media pembelajaran, dan evaluasi yang akan digunakan pada pelaksanaan pembelajaran. Pelaksaan pembelajaran dilakukan dengan menyiapkan materi yang akan digunakan dan tahap terakhir memberikan soal tes evaluasi kepada siswa.

Pembelajaran daring di siklus 1 dengan tema 7 sub tema 3 pembelajaran ke 1 yang didesain dengan pembelajaran PBL, hasil refleksi pra siklus, siklus 1 dan siklus II secara rinci tersaji pada tabel 1 berikut.

Tabel 1. Hasil Belajar Tematik Berdasarkan Ketuntasan Prasiklus sampai Siklus II

\begin{tabular}{ccccc}
\hline Skor & Kriteria & $\begin{array}{c}\text { Pra siklus } \\
\mathbf{F} \%\end{array}$ & $\begin{array}{c}\text { Siklus I } \\
\text { F } \%\end{array}$ & $\begin{array}{c}\text { Siklus II } \\
\mathbf{F} \%\end{array}$ \\
\hline$<80$ & Tidak Tuntas & 9 & 15 & 19 \\
$\geq 80$ & Tuntas & $42,86 \%$ & $71,42 \%$ & $90,47 \%$ \\
\hline
\end{tabular}


Jurnal Mimbar IImu, Vol. 26 No. 1, 2021

P-ISSN: 1829-877X E-ISSN: 2685-9033

\begin{tabular}{ccccc}
\hline \multirow{2}{*}{ Skor } & \multirow{2}{*}{ Kriteria } & Pra siklus & Siklus I & Siklus II \\
& & F \% & F \% & F \% \\
\hline \multirow{2}{*}{ Jumlah } & $57,14 \%$ & $28,58 \%$ & $9,53 \%$ \\
\hline \multirow{2}{*}{} & $\mathbf{2 1}$ & $\mathbf{2 1}$ & $\mathbf{2 1}$ \\
& $\mathbf{1 0 0} \%$ & $\mathbf{1 0 0 \%}$ & $\mathbf{1 0 0 \%}$ \\
\hline
\end{tabular}

Berdasarkan tabel 1 di atas menunjukkan bahwa pada kondisi pra siklus, siswa yang tuntas mencapai $42,86 \%$. Kondisi tersebut belum sesuai harapan, perlu diupayakan untuk $100 \%$ siswa tuntas belajar. Upaya yang dilakukan dengan memberi tindakan pembelajaran PBL. Pembelajaran dengan PBL menggunakan langkah-langkah sebagai berikut: a) Menyimak masalah gaya dalam teks nonfiksi di kelompok b) Menganalisis masalah gaya yang ada dalam teks nonfiksi c) Mengajukan pertanyaan mengenai masalah gaya d) Mengamati gaya di sekelilingnya e) Membuat laporan tentang gaya dalam bentuk teks nonfiksi f) Mempresentasikan hasil laporan gaya dalam bentuk teks nonfiksi. Hasil dari pemberian tindakan tersebut, ketuntasan belajar siswa sebesar $71,42 \%$ dari seluruh siswa. Perolehan tersebut dikarenakan tindakan yang melibatkan siswa dalam belajar untuk memecahkan permasalahan. Hasil dari tindakan nampak bahwa ada peningkatan hasil belajar tematik, namun hasil yang diperoleh pada siklus I belum memenuhi indikator keberhasilan yang telah ditentukan sebesar $75 \%$ dari seluruh siswa sehingga perlu diberi tindakan lagi dalam siklus II.

Hasil pembelajaran PBL siklus II dengan tema 7 sub tema 2 pembelajaran ke 1, sebesar $90,47 \%$ dari seluruh siswa telah tuntas yang ditandai skor $\mathrm{KKM} \geq 80$. Peningkatan persentase ketuntasan dari pra siklus, siklus I dan siklus II, membuktikan bahwa terjadi peningkatan hasil belajar tematik siswa kelas IV SD dalam pembelajaran daring melalui PBL (sesuai hipotesis/judul/masalah).

Pada siklus I keterlibatan siswa belum optimal, hal ini disebabkan siswa yang belum terbiasa dengan pembelajaran berbasis masalah, belum memahami persoalan yang disajikan oleh guru dan pemahaman dasar memecahkan masalah yang di miliki siswa masih kurang. Nampak dalam pembelajaran pada saat guru memberikan permasalahan, tidak semua siswa memahami permasalahan yang diberikan oleh guru sehingga ada beberapa siswa yang bertanya dan meminta guru untuk menjelaskan lagi permasalahan yang diberikan. Namun, diskusi dan tanya jawab sudah mulai dilakukan dalam pembelajaran dan siswa mulai dilibatkan secara aktif ketika pembelajaran berlangsung meskipun belum berlangsung secara maksimal.

Pada siklus II keterlibatan siswa mulai mengalami peningkatan dalam menyelesaikan LKPD. Hal itu menunjukkan bahwa siswa sudah mulai terbiasa dengan penyelesaian soal yang berbasis masalah secara berkelompok serta pemahaman dasar memecahkan masalah dalam menyelesaikan soal siswa sudah mulai menunjukkan peningkatan. Siswa mulai aktif berdiskusi untuk menyelesaikan permasalahan yang disajikan oleh guru. Kemampuan menanya dan memilih cara untuk menyelesaikan masalah sudah tepat. Siswa mulai percaya diri dalam mengkomunikasikan jawaban yang diperoleh dari diskusi. Aktivitas siswa yang semakin meningkat sehingga berdampak pada hasil tes yang semakin membaik. Hal itu menunjukkan bahwa siswa sudah mulai terbiasa dengan penyelesaian masalah secara berkelompok sehingga siswa mengalami peningkatan setelah melakukan pembelajaran dengan PBL dan memenuhi indikator keberhasilan

Skor rata-rata hasil belajar pada pra siklus, siklus I, dan siklus II adalah 65,$14 ; 82,14$; dan 94,05. Analisis perbedaan rata-rata ini juga diolah menggunakan analisis uji T. Output uji T disajikan pada tabel 2 berikut. 
Tabel 2. Uji TOne-Sample Test

\begin{tabular}{|c|c|c|c|c|c|c|c|}
\hline & \multicolumn{7}{|c|}{ Test Value $=80$} \\
\hline & \multirow[t]{2}{*}{$t$} & \multirow[t]{2}{*}{ df } & \multirow[t]{2}{*}{$\begin{array}{c}\text { Sig. } \\
(2- \\
\text { tailed) }\end{array}$} & \multirow[t]{2}{*}{$\begin{array}{c}\text { Mean } \\
\text { Difference }\end{array}$} & \multirow[t]{2}{*}{$\begin{array}{l}\text { Std. Error } \\
\text { Difference }\end{array}$} & \multicolumn{2}{|c|}{$\begin{array}{l}95 \% \text { Confidence } \\
\text { Interval of the } \\
\text { Difference }\end{array}$} \\
\hline & & & & & & Lower & Upper \\
\hline Hasil Belajar & 3,212 & 48 & .000 & 6,560 & 2,143 & 2,245 & 10,875 \\
\hline
\end{tabular}

Tabel 1 menunjukkan bahwa t hitung 3,21 > 1,74 sehinggadapat disimpulkan bahwa terdapat perbedaan rata-rata hasil belajar siswa antara pra siklus, siklus I dan siklus II yang signifikan, artinya perbedaan rata-rata hasil belajar bermakna.

Uji gain ternormalisasi (N-Gain) dilakukan untuk mengetahui peningkatan hasil belajar kognitif siswa setelah diberikan perlakuan. Peningkatan ini diambil dari nilai pretest dan posttest yang didapatkan oleh siswa. Gain ternormalisasi atau yang disingkat dengan NGain merupakan perbandingan skor gain aktual dengan skor gain maksimum (Richard R. Hake, 1998: 65). Hasil analisis uji N-Gain secara rinci disajikan melalui tabel 4 berikut.

Tabel 3. Uji N-Gain

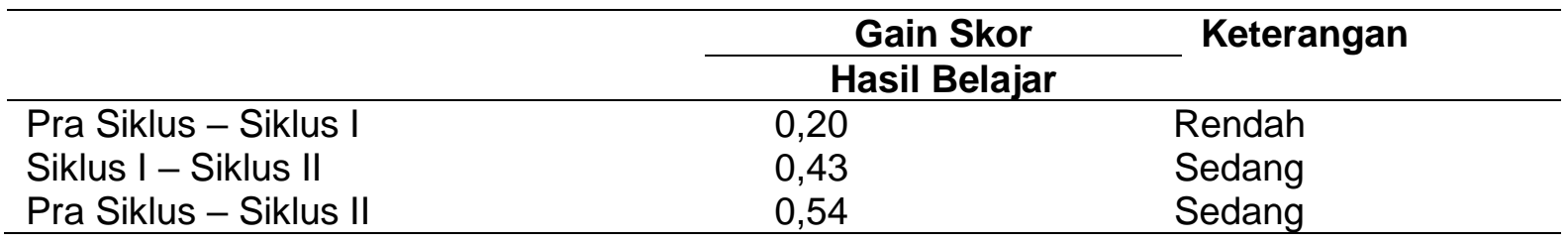

Berdasarkan tabel 3. menunjukkan bahwa peningkatan hasil belajar tematik dari pra siklus ke siklus I sebesar 0,20 termasuk dalam kategori rendah. Pada siklus 1 ke siklus II sebesar 0,43 termasuk dalam kategori sedang dan pra siklus ke siklus II sebesar 0,54 termasuk dalam kategori sedang. Rata-rata gain ternormalisasi yang lebih tinggi pada pra siklus ke siklus II menunjukkan bahwa peningkatan skor hasil belajar tematik merupakan pengaruh dari diberikannya tindakan pelaksanaan pembelajaran melalui PBL.

Berdasarkan hasil refleksi siklus 1 terdapat 5 siswa yang belum berani untuk menjawab pertanyaan dari guru, 2 siswa yang belum percaya diri untuk berdiskusi dengan teman dan belum berpikir kritis terhadap suatu masalah. Semua aktivitas belajar baik guru maupun siswa telah dilaksanakan, akan tetapi pelaksanaannya kurang optimal. Pelaksanaan pembelajaran yang optimal dapat tercapai dengan dilakukan perbaikan pembelajaran melalui siklus II. Pelaksanaan pembelajaran tematik siklus II dilaksanakan dalam dua kali pertemuan dengan tahapan yaitu tahap perencanaan, tahap pelaksanaan tindakan dan observasi, dan tahap refleksi. Aktivitas pembelajaran yang dilakukan oleh guru dan siswa dalam siklus 2 , dilakukan secara rinci melalui penjelasan berikut ini. Tahap perencanaan dilakukan dengan guru membuat perangkat pembelajaran.

Pada tahap pelaksanaan tindakan akan diuraikan tentang proses pelaksanaan tindakan, hasil tindakan, dan hasil observasi. Proses pelaksanaan tindakan mendeskripsikan tentang pelaksanaan tindakan siklus II dari awal sampai akhir pembelajaran pada setiap pertemuan. Pelaksanaan tindakan siklus II dilakukan sebanyak tiga kali pertemuan. Pertemuan I, kegiatan yang dilakukan guru pada awal pembelajaran adalah membagikan bahan ajar, link LKPD liveworksheet, dan link zoom yang dibagikan melalui WAG. Pada saat zoom, guru mengucapkan salam, salah satu peserta didik memimpin doa, guru melakukan presensi dengan meminta peserta didik untuk membuka kamera. Apersepsi dilakukan melalui tanya jawab guru dengan siswa tentang indahnya keragaman di negeriku. Guru menyampaikan tujuan pembelajaran yang akan dicapai oleh siswa. Respon siswa sangat antusias dan bersemangat dalam mengikuti pembelajaran. 
Pada kegiatan inti, siswa menganalisis teks bacaan nonfiksi tentang gaya magnet dan gaya gravitasi, kemudian siswa diminta menyampaikan pendapat yang ada di teks bacaan pada LKPD 1 di liveworksheet. Siswa mendengarkan pokok permasalahan yang disampaikan oleh guru mengenai gaya magnet dan gaya gravitasi. Siswa berdiskusi mengenai langkah-langkah yang harus dilakukan untuk memecahkan masalah terkait dengan gaya magnet dan gaya gravitasi. Guru membantu siswa dalam berdiskusi dengan menanyakan kepada siswa tentang kesulitan apa yang dialami. Tidak ada siswa yang menanyakan mengenai permasalahan yang diberikan dan langkah-langkah kegiatan yang harus dilakukan karena belum memahaminya. Siswa sudah terlihat aktif dalam berdiskusi dan mencari tahu informasi untuk memecahkan permasalah yang diberikan dengan mengamati percobaan yang sedang dilakukan. Pada pembelajaran tersebut juga terlihat tidak ada siswa yang diam dan tidak memberikan pendapat atau diskusi dengan temannya. Langkah yang dilakukan siswa setelah menyelesaikan percobaan yaitu membuat laporan hasil percobaan dalam bentuk teks nonfiksi pada LKPD 1 di liveworksheet. Perwakilan siswa mempresentasikan hasil laporan percobaannya yang ada di LKPD 1 liveworksheet melalui zoom. Siswa memperhatikan umpan balik yang diberikan guru.

Kegiatan akhir, siswa bersama guru menyimpulkan kegiatan pembelajaran yang telah dipelajari dan melakukan refleksi pembelajaran. Siswa juga diberi kesempatan untuk bertanya tentang materi yang belum jelas dan pembelajaran diakhiri dengan berdoa dan guru mengucapkan salam penutup. Pertemuan II diuraikan dengan kegiatan awal pembelajaran yang dilakukan guru adalah membagikan bahan ajar, link LKPD liveworksheet, dan link zoom yang dibagikan melalui WAG. Pada saat zoom, guru mengucapkan salam, salah satu peserta didik memimpin doa, guru melakukan presensi dengan meminta peserta didik untuk membuka kamera. Apersepsi dilakukan melalui tanya jawab guru dengan siswa tentang indahnya keragaman di negeriku. Guru menyampaikan tujuan pembelajaran yang akan dicapai oleh siswa. Respon siswa semakin antusias dan terlihat lebih senang dalam mengikuti pembelajaran daripada pembelajaran sebelumnya.

Kegiatan pendahuluan selesai, dilanjutkan dengan kegiatan inti. Pada kegiatan inti, guru menayangkan video "penggunaan gaya magnet dan gaya gravitasi dalam kehidupan sehari-hari". Siswa menganalisis video yang ditayangkan pada ppt, kemudian siswa diminta menyampaikan pendapat tentang penggunaan gaya magnet dan gaya gravitasi yang ada divideo. Siswa mendengarkan pokok permasalahan yang disampaikan oleh guru mengenai penggunaan gaya magnet dan gaya gravitasi. Siswa berdiskusi mengenai langkah-langkah yang harus dilakukan untuk memecahkan masalah terkait dengan penggunaan gaya magnet dan gaya gravitasi. Guru membantu siswa dalam berdiskusi dengan menanyakan kepada siswa tentang kesulitan apa yang dialami. Secara keseluruhan, siswa terlihat aktif dalam berdiskusi dan mencari tahu informasi untuk memecahkan permasalah yang diberikan dengan mengamati percobaan yang sedang dilakukan. Pada pembelajaran tidak ada siswa yang diam dan tidak memberikan pendapat dengan temannya. Langkah yang dilakukan siswa setelah menyelesaikan percobaan yaitu membuat laporan hasil percobaan dalam bentuk teks nonfiksi pada LKPD 2 di liveworksheet. Perwakilan siswa mempresentasikan hasil laporan percobaannya pada LKPD 2 di liveworksheet melalui zoom. Siswa memperhatikan umpan balik yang diberikan guru.

Pada kegiatan akhir pembelajaran, siswa bersama guru menyimpulkan hasil kegiatan pembelajaran yang telah dipelajari dan melakukan refleksi pembelajaran. Siswa juga diberi kesempatan untuk bertanya tentang materi yang belum jelas dan untuk mengakhiri pelajaran dengan berdoa dan mengucapkan salam penutup. Pertemuan III pembelajaran diawali dengan guru membagikan link zoom yang dibagikan melalui WAG, guru mengucapkan salam. salah satu peserta didik memimpin doa. guru melakukan presensi dengan meminta siswa membuka kamera. Siswa diberi soal evaluasi yang dikirimkan melalui link quizizz untuk mengetes sejauh mana pemahaman siswa yang sudah dipelajari. Pada kegiatan akhir, siswa diberi kesempatan untuk bertanya tentang materi yang belum jelas. Pembelajaran diakhiri dengan berdoa dan guru memberikan salam penutup. Dapat disimpulkan bahwa 
model pembelajaran PBL berpengaruh pada hasil belajar tematik siswa. Hal ini disebabkan oleh beberapa faktor yaitu sebagai berikut.

Pertama, model pembelajaran Problem Based Learning dapat membantu siswa dalam belajar. Saat pembelajaran berlangsung siswa diberi kesempatan untuk bertanya tentang materi yang belum jelas sehingga dapat memudahkan siswa dalam belajar (Budiana, Sudana, \& Suwatra, 2013; Diah \& Riyanto, 2016). Peningkatan hasil belajar siswa kelas IV SD melalui PBL dalam pembelajaran daring dengan langkah-langkah a) Menyimak masalah gaya dalam teks nonfiksi di kelompok b) Menganalisis masalah gaya yang ada dalam teks nonfiksi c) Mengajukan pertanyaan mengenai masalah gaya d) Mengamati gaya di sekelilingnya e) Membuat laporan tentang gaya dalam bentuk teks nonfiksi f) Mempresentasikan hasil laporan gaya dalam bentuk teks nonfiksi. Pendekatan pembelajaran berbasis masalah ini membuat siswa lebih aktif, kreatif, dan inovatif dalam meningkatkan kemampuan memecahkan masalah sehingga hasil belajar siswa dapat meningkat (Asriningtyas, Nandhita, \& Anugraheni, 2018; Winoto \& Prasetyo, 2020).

Kedua, model pembelajaran Problem Based Learning dapat membuat suasana belajar lebih menyenangkan sehingga siswa merasa nyaman dalam belajar. Siswa berdiskusi dengan temannya mengenai langkah-langkah yang harus dilakukan untuk memecahkan masalah yang telah diberikan oleh guru. Guru membantu siswa dalam berdiskusi dengan menanyakan kepada siswa tentang kesulitan apa yang dialami. Kegiatan pembelajaran seperti ini dapat menciptakan suasana belajar yang nyaman dan menyenangkan (Astari, Suroso, \& Yustinus, 2018; Tiwari, Lai, So, \& Yuen, 2006). Pada saat pembelajaran berlangsung, tidak ada siswa yang diam dan tidak memberikan pendapat dengan temannya sehingga seluruh siswa terlibat aktif dalam belajar. Ngalimun (2013) menyatakan bahwa PBL merupakan suatu pembelajaran yang melibatkan siswa untuk memecahkan suatu masalah melalui tahap-tahap metode ilmiah sehingga siswa dapat mempelajari pengetahuan yang berhubungan dengan masalah tersebut sekaligus memiliki keterampilan untuk memecahkan masalah.

Rochmad \& Ulinnuha (2020), Ridlo (2020), Mulyanto et al (2020) mengemukakan bahwa diperlukan waktu dan pertemuan untuk meningkatkan hasil belajar siswa dengan pendekatan pembelajaran yang sama. Oleh karena itu, perlu dilakukan pembelajaran PBL lebih lama lagi untuk meningkatkan hasil belajar siswa. Penelitian yang dilakukan oleh Suari, Ni (2018) hasil penelitian menunjukkan bahwa melalui pendekatan PBL, pada siklus 1 siswa mencapai ketuntasan sebanyak 16 siswa (64\% dari 25 siswa) dan pada siklus 2 hasil belajar yang mencapai ketuntasan mencapai 22 siswa (88\% dari 25 siswa). Peningkatan hasil belajar yang diperoleh siklus II lebih tinggi dibandingkan siklus I dikarenakan pada siklus I siswa baru pertama kali menggunakan PBL. Penelitian yang dilakukan oleh Jahro \& Ridho (2015) juga menyatakan bahwa model pembelajaran PBL dapat meningkatkan hasil belajar dan kerjasama siswa. Dapat disimpulkan bahwa disimpulkan bahwa terjadi peningkatan hasil belajar siswa kelas IV SD melalui Problem Based Learning (PBL) dalam pembelajaran daring terbukti dan peningkatan hasil belajar siswa kelas IV SD melalui langkah-langkah pendekatan PBL. Implikasi penelitian ini berdampak pada terciptanya suasana belajar yang menyenangkan sehingga membuat siswa terlibat penuh dalam belajar serta dapat meningkatkan sikap kerjasama antar siswa sehingga berpengaruh pada hasil belajar siswa yang meningkat.

\section{Simpulan}

Model pembelajaran Problem Based Learning (PBL) mempengaruhi hasil belajar Tematik pada siswa. Dapat disimpulkan bahwa Model pembelajaran Problem Based Learning (PBL) dapat meningkatkan hasil belajar siswa kelas IV SD. 


\section{Daftar Pustaka}

Abdulloh, R. S. (2015). Pembelajaran Saintifik untuk Implementasi Kurikulum 2013. Jakarta: Bumi Aksara.

Arianti, N. M., Wiarta, I. W., \& Darsana, I. W. (2019a). Pengaruh Model Pembelajaran Problem Posing Berbantuan Media Semi Konkret terhadap Kompetensi Pengetahuan Matematika. Jurnal IImiah Sekolah Dasar, 3(4). https://doi.org/10.23887/jisd.v3i4.21765

Arianti, Wiarta, \& Darsana. (2019b). Pengaruh Model Pembelajaran Problem Posing Berbantuan Media Semi Konkret terhadap Kompetensi Pengetahuan Matematika. Jurnal Ilmiah Sekolah Dasar Undiksha, 3(4). https://doi.org/http://dx.doi.org/10.23887/jisd.v3i4.21765

Asriningtyas, Nandhita, \& Anugraheni. (2018). Penerapan Model Pembelajaran Problem Based Learning Untuk Meningkatkan Kemampuan Berpikir Kritis Dan Hasil Belajar Matematika Siswa Kelas 4 SD. JKPM, 5(1), 23-32. https://doi.org/https://doi.org/10.26714/jkpm.5.1.2018.23-32

Astari, F. A., Suroso, S., \& Yustinus, Y. (2018). Efektifitas Penggunaan Model Discovery Learning Dan Model Problem Based Learning Terhadap Hasil Belajar Ipa Siswa Kelas 3 Sd. Jurnal Basicedu, 2(1), 1-10. https://doi.org/10.31004/basicedu.v2i1.20

Batubara, H. H., \& Batubara, D. S. (2020). Penggunaan Video Tutorial Untuk Mendukung Pembelajaran Daring Di Masa Pandemi Virus Corona. Muallimuna: Jurnal Madrasah Ibtidaiyah, 5(2), 21. https://doi.org/10.31602/muallimuna.v5i2.2950

Budiana, Sudana, \& Suwatra. (2013). Pengaruh Model Creative Problem Solving ( CPS ) Terhadap Kemampuan Berpikir Kritis Siswapada Mata Pelajaran IPA Siswa Kelas V SD. Mimbar PGSD Undiksha, https://doi.org/http://dx.doi.org/10.23887/jjpgsd.v1i1.816

Diah, \& Riyanto. (2016). Problem-Based Learning Model In Biology Education Courses To Develop Inquiry Teaching Competency Of Preservice Teachers. Cakrawala Pendidikan, 35(1), 47-57. https://doi.org/https://doi.org/10.21831/cp.v1i1.8364

Febrita, I., \& Harni. (2020). Model Problem Based Learning dalam Pembelajaran Tematik Terpadu terhadap Berfikir Kritis Siswa di Kelas IV SD. Jurnal Pendidikan Tambusai, 4(2), 1619-1633. Retrieved from https://jptam.org/index.php/jptam/article/view/627

Firdaus, F. M., \& Badriyah, N. (2018). Penerapan Pembelajaran Tematik Berbasis Budaya Betawi untuk Meningkatkan Logical Intelligence Siswa SD Islam Taman Qur'aniyah Jakarta Selatan. Al Ibtida: Jurnal Pendidikan Guru MI, 5(1), 95. https://doi.org/10.24235/al.ibtida.snj.v5i1.2727

Hajar, I. (2013). Panduan Lengkap Kurikulum Tematik Untuk SD/MI. Yogyakarta: Diva Press. Isman. (2017). 58 Model Pembelajaran Inovatif. Medan: Media Persada.

Jahro, S., \& Ridho, D. (2015). Penerapan Model Problem Based Learning Menggunakan Media Exe Learning untuk Meningkatkan Hasil Belajar dan Kerjasama Siswa Pada Materi Hidrokarbon. Jurnal Pendidikan Kimia, 7(3), 80-86. https://doi.org/https://doi.org/10.24114/jpkim.v7i3.4261

Jamil, S. (2014). Strategi Pembelajaran. Yogyakarta: Ar-ruzz Media.

Khoeriyah, N., \& Mawardi, M. (2018). Penerapan Desain Pembelajaran Tematik Integratif Alternatif Berbasis Kearifan Lokal untuk Meningkatkan Hasil dan Kebermaknaan Belajar. Mimbar Sekolah Dasar, 5(2), 63. https://doi.org/10.17509/mimbarsd.v5i2.11444 
Lattu, D. (2012). Peran Guru Bimbingan dan Konseling pada Sekolah Penyelenggara Pendidikan Inklusi. Jurnal Bimbingan Dan Konseling Terapan, 2(1). https://doi.org/http://dx.doi.org/10.30598/jbkt.v2i1.236

Mulyadin. (2016). Implementasi Kebijakan Pembelajaran Tematik Terpadu Kurikulum 2013 Di SDN Kauman 1 Malang Dan Sd Muhammadiyah 1 Malang. Jurnal Pendidikan Edutama, 3(2), 31 - 48. https://doi.org/http://dx.doi.org/10.30734/jpe.v3i2.35

Mulyanto, B. S., Sadono, T., Koeswanti, H. D., Dasar, S., Wonodoyo, N., Tengah, J., ... Tengah, J. (2020). Evaluation of Critical Thinking Ability with Discovery Lerning Using Blended Learning Approach in Primary School. Journal of Educational Research and Evaluation, 9(2), 78-84. https://doi.org/https://doi.org/10.15294/jere.v9i2.46135

Mustikaningrum, G., Pramusinta, L., Ayu, S., \& Umar, M. (2020). Implementasi Pendidikan Karakter Terintegrasi Kurikulum Dan Metode Pembelajaran Pada Masa Pandemi Covid-19. AULADUNA: Jurnal Pendidikan Dasar Islam, 7(2), 154-164. https://doi.org/https://doi.org/10.24252/10.24252/auladuna.v7i2a5.2020

Nakayama, M., Yamamoto, H., \& Santiago, R. (2007). The Impact of Learner Characteristics on Learning Performance in Hybrid Courses among Japanese Students. Electronic Journal E-Learning, 5(3), 195-206. Retrieved from https://eric.ed.gov/?id=EJ1098825

Ngalimun. (2013). Perkembangan dan Pengembangan Kreativitas. Yogyakarta: Aswaja Pressindo.

Phungsuk, R., Viriyavejakul, C., \& Ratanaolarn, T. (2017). Development of a problem-based learning model via a virtual learning environment. Kasetsart Journal of Social Sciences, 38(3), 297-306. https://doi.org/10.1016/j.kjss.2017.01.001

Prasetya, Ade Yama Wahyu Nur, Dedi Kuswandi, S. A. (2018). Multimedia Interaktif pada Pembelajaran Tematik untuk Kelas IV Sekolah Dasar. Jurnal Pendidikan: Teori, Penelitian, Dan Pengembangan, 3(11), 1423-1427. https://doi.org/http://dx.doi.org/10.17977/jptpp.v3i11.11751

Ridlo, S. (2020). Critical Thinking Skills Reviewed from Communication Skills of the Primary School Students in STEM-Based Project-Based Learning Model. Journal of Primary Education, 9(3), 311-320. https://doi.org/https://doi.org/10.15294/jpe.v9i3.27573

Rochmad, R., \& Ulinnuha, R. (2020). Blended learning Menggunakan Gnomio untuk Meningkatkan Kemampuan Berpikir Kreatif Matematis Siswa SMP. PRISMA, Prosiding Seminar Nasional Matematika, 3, 476-481. Retrieved from https://journal.unnes.ac.id/sju/index.php/prisma/article/view/37647

Şendağ, S., \& Ferhan Odabaşi, H. (2009). Effects of an online problem based learning course on content knowledge acquisition and critical thinking skills. Computers and Education, 53(1), 132-141. https://doi.org/10.1016/j.compedu.2009.01.008

Setyosari, P. (2017). Menciptakan Pembelajaran Yang Efektif Dan Berkualitas. JINOTEP (Jurnal Inovasi Dan Teknologi Pembelajaran) Kajian Dan Riset Dalam Teknologi Pembelajaran, 1(5), 20-30. https://doi.org/10.17977/um031v1i12014p020

Suari, Ni, P. (2018). Penerapan Model Pembelajaran Problem Based Learning Untuk Meningkatkan Motivasi Belajar IPA. Jurnal IImiah Sekolah Dasar, 2(3), 241-247. https://doi.org/http://dx.doi.org/10.23887/jisd.v2i3.16138

Tafqihan, Z. (2011). Karakteristik Dan Pemilihan Media Pembelajaran Dalam E-Learning. Cendekia: Jurnal Kependidikan Dan Kemasyarakatan, 9(2), 141-154. https://doi.org/https://doi.org/10.21154/cendekia.v9i2.871

Tiwari, A., Lai, P., So, M., \& Yuen, K. (2006). A comparison of the effects of problem-based learning and lecturing on the development of students' critical thinking. Medical Education, 40(6), 547-554. https://doi.org/10.1111/j.1365-2929.2006.02481.x 
Ulinnuha, R., Budi Waluya, S., \& Rochmad, R. (2021). Creative Thinking Ability With OpenEnded Problems Based on Self-Efficacy in Gnomio Blended Learning. Unnes Journal of Mathematics Education Research, 10(A), 20-25. Retrieved from https://journal.unnes.ac.id/sju/index.php/ujmer/article/view/34277

Wardani. (2010). Penelitian Tindakan Kelas. Jakarta: Universitas Terbuka.

Winoto, Y. C., \& Prasetyo, T. (2020). Efektivitas Model Problem Based Learning Dan Discovery Learning Terhadap Kemampuan Berpikir Kritis Siswa Sekolah Dasar. Jurnal Basicedu, 4(2), 228-238. https://doi.org/10.31004/basicedu.v4i2.348

Wulandari, Sudatha, \& Simamora. (2020). Pengembangan Pembelajaran Blended Pada Mata Kuliah Ahara Yoga Semester II di IHDN Denpasar. Jurnal Edutech Undiksha, 8(1), 1-15. https://doi.org/http://dx.doi.org/10.23887/jeu.v8i1.26459

Wuryani, M. T., \& Yamtinah, S. (2018). Textbooks Thematic Based Character Education on Thematic Learning Primary School: An Influence. International Journal of Educational Methodology, 4(2), 75-81. https://doi.org/10.12973/ijem.4.2.75

Wyness, L., \& Dalton, F. (2018). The value of problem-based learning in learning for sustainability: Undergraduate accounting student perspectives. Journal of Accounting Education, 45, 1-19. https://doi.org/https://doi.org/10.1016/j.jaccedu.2018.09.001

Yuniawardani, V., \& Mawardi. (2018). Peningkatan Hasil Belajar Pada Pembelajaran Matematika Dengan Model Problem Based Learning Kelas IV SD. Jurnal Riset Teknologi Dan Inovasi Pendidikan, 1(2), 24-32. https://doi.org/https://doi.org/10.31764/justek.v1i1.416 